\title{
Manajemen Komunikasi Publikasi Kegiatan Masjid Agung Trans Studio Bandung
}

\author{
Siti Mariyam ${ }^{1 *}$, Yusuf Zaenal Abidin ${ }^{2}$, Imron Rosyidi ${ }^{2}$ \\ 1Jurusan Komunikasi dan Penyiaran Islam, Fakultas Dakwah dan Komunikasi, \\ UIN Sunan Gunung Djati, Bandung \\ ${ }^{2}$ Prodi Komunikasi dan Penyiaran Islam, Program Pascasarjana, \\ UIN Sunan Gunung Djati, Bandung \\ *Email : sitiitumariyam@gmail.com
}

\begin{abstract}
Trans Studio Mosque Bandung is a mosque located in the area of amusement park in cooperation with many partners ta'lim so always crowded by thousands of people to witness the study of Islam. The purpose of this study is to know the planning, organizing, implementation and supervision of information publication activities conducted study by DKM mosque Trans Studio Bandung. Research method used in this research is Descriptive method, and Communication management approach. While the data collection techniques used in this study are documentation, observation and interview techniques. The results of this study show that: (1) Planning of the publication of activities undertaken includes: a) timing of activities, b) determination of the study filler, c) making theme of the activity, and d) making of activity poster. (2) The organization of the publication of activities shall only be undertaken by the public relation departement field. (3) The implementation of the publication shall be: a) acceptance of the activities of the ta'lim partner, b) discuss the filler and the theme of the study; c) accept the study poster and revise it if necessary; d) publish on all social media accounts. 4) Supervision of the publication of information on activities conducted under the knowledge of the Board of Trustees Prof. KH Miftah Faridl.
\end{abstract}

Keywords: Communication Management; TSM Mosque; Mosque Management

\begin{abstract}
ABSTRAK
Mesjid Agung Trans Studio Bandung merupakan masjid yang berada di kawasan taman hiburan yang bekerjasama dengan banyak mitra ta'lim sehingga selalu ramai didatangi oleh ribuan orang utnuk menyaksikan kajian keislaman. Tujuan penelitian ini adalah untuk mengetahui perencanaan, pengorganisasian, pelaksanaan dan pengawasan kegiatan publikasi informasi kajian yang dilakukan oleh DKM masjid Trans Studio Bandung. Metode Penelitian yang digunakan dalam penelitian ini adalah metode Deskriptif, dan pendekatan manajemen Komunikasi. Sedangkan teknik pengumpulan data yang digunakan dalam penelitian ini adalah teknik dokumentasi, observasi dan wawancara. Hasil dari penelitian ini menunjukan bahwa: (1) Perencanaan publikasi kegiatan yang
\end{abstract}


dilakukan meliputi: a) pencanangan waktu kegiatan, b) penentuan pengisi kajian, c) pembuatan tema kegiatan, dan d) pembuatan poster kegiatan. (2) Pengorganisasian publikasi kegiatan hanya dilakukan oleh bidang Humas (3) Pelaksanaan publikasi yang dilakukan adalah : a) penerimaan ajuan kegiatan dari mitra ta'lim, b) mendiskusikan pengisi dan tema kajian, c) menerima poster kajian dan merevisinya jika perlu, dan d) publikasikan di semua akun media sosial. 4) Pengawasan publikasi informasi kegiatan yang dilakukan dibawah sepengetahuan Dewan Pembina Prof. KH Miftah Faridl.

Kata Kunci : Manajemen Komunikasi; Masjid TSM; Manajemen Masjid

\section{PENDAHULUAN}

Mesjid Agung Trans Studio Bandung merupakan masjid yang berada di kawasan taman hiburan. Berdasarkan letak strategis ekonomis maka tentu akan sangat banyak pengunjung yang datang kekewasan tersebut dengan bertujuan untuk berlibur. Meskipun masjid ini dibangun diluar master plan, namun berdasarkan mayoritas kebutuhan pengungjung untuk beribadah yaitu umat muslim untuk melaksanakan sholat maka masjid tersebut dibangun sebelum pintu masuk kawasan Trans Studio Bandung.

Tidak berhenti pada pelaksanaan sholat 5 waktu saja, DKM masjid berupaya untuk memakmurkannya juga dengan kegiatan-kegiatan Islami. Mengundang beberapa tokoh dan penggerak dakwah di kalangan pemuda dan bekerjasama dengan berbagai macam mitra ta'lim maka sampai saat ini pada sore atau malam hari selalu ramai didatangi oleh ribuan orang utnuk menyaksikan kajian. Dengan demikian, penelitian ini dimaksudkan untuk mengetahui manajemen komunikasi yang dilakukan DKM sehingga kajian tersebut selalu berhasil mendatangkan ribuan jamaah. Berikut ini kesaksian dari salah satu peserta kajian dari komunitas Pemuda Hijrah:

Daya tampung masjid mah kurang lebih 1.500 sampai dengan 2.000 orang, dan seriang pelaksanaan kajian jamaah selalu sampai luar masjid. Jadi dalam satu kali kajian selalu dihadiri oleh minimal 2.000 orang, itu hanya yang di dalam masjid belum yang diluar. Jamaah yang di luar bisa sampai kurang lebih 1.500 orang (hasil wawancara dengan Figa Bhiranovot di pasar Ciwastra pada hari Sabtu, 26 Mei 2018 pukul 17.45 WIB).

Media publikasi yang dimiliki DKM adalah website, facebook, youtbe, tweeter dan instagram. Pengurus DKM memandang bahwa akun instagram yang bernama@masjidtrans lebih efektif karena sedang digunakan oleh kalangan pemuda. Instagram merupakan media yang dipilih oleh DKM karena saat ini cukup efektif dikalangan pemuda dan remaja. Followers atau pengikut dari akun instagram tersebut sudah mencapai 111.000 followers atau 111.000 pengikut. Artinya, 111.000 orang telah mengikuti postingan foto dan video yang diunggah langsung dari akun@masjidtrans. (hasil wawancara dengan bidang Humas, bpk. Jajat di kantor DKM pada hari Senin, 05 Maret 2018 pukul 14.55 WIB) 
Melalui chenel youtube ini, setiap orang dapat menyaksikan muballigh yang menyampaikan ajaran-ajaran Islam dengan media audio visual. Bukan hanya sekedar menulis dan berbicara di atas mimbar, kegiatan tabligh yang di laksanakan oleh pengurus DKM Masjid Agung Trans Studio Bandung juga melalui on camera atau di depan kamera yang langsung di upload atau diunggah di channel youtube. orang-orang pun di sedikit yang menonton video tersebut. secara tidak langsung, video yang ada di youtube itu sudah menyiarkan ajaran-ajaran Islam. Memanfaatkan media instagram dan you tube merupakan hal mudah yang dapat dilakukan oleh siapa pun dan kapan pun, namun ada sesuatu yang belum diketahui penjungjang-penunjang keberhasilah komunikasi yang dilakukan DKM masjid ini.

Fungsi utama masjid adalah tempat sujud kepada Allah SWT, tempat shalat dan tempat beribadah kepada Nya. Lima kali hari semalam umat Islam dianjurkan mengunjungi masjid guna melaksanakan shalat berjamaah. Masjid juga merupakan tempat yang paling banyak di kumandangkan nama Allah melalui adzan, qamat, tasbih, tahmid, tahlil, istigfar, dan ucapan lain yang dianjurkan dibaca di masjid sebagai bagian dari lafaz yang berkaitan dengan pengagungan asma Allah (Ayub dkk., 1996: 7). Pada dasarnya mengguakan media instagram dan youtube merupakan proses komunikasi. Prose komunikasi itu dapat dikatakan efektif karena setiap publikasi kegiatan kajian selalu ramai dihadiri jamaah.

Pada dasarnya optimalisasi publikasi kegiatan dapat dikatakan berhasil dan efektif, hal ini dibuktikan pada membludaknya para jamaah pengajian pada setiap pelaksanaan kajian Islami tersebut. Komunikasi seperti apa yang dilakukan Masjid Agung Trans Studio Bandung sehingga dapat memberikan efektifitas yang luarbiasa. Maka untuk dapat mengetahui media apa yang digunakan Masjid Agung Trans Studio Bandung dalam publikasi kegiatan-kegiatan masjidnya dan bagaimana media yang dipilih dapat menimbulkan efek yang diharapkan penelitian tentang manajemen komunikasi komunikasinya sangat perlu untuk dilakukan.

DKM merupakan salahsatu organisasi yang memiliki visi dan misi. Untuk dapat efektif dan efesien sampai pada tujuan organisasi tersebut maka diperlukan manajemen harus difungsikan sepenuhnya pada setiap lembaga atau organisasi, industri, perbankan, perusahaan, maupun pendidikan. Siagian (1997: 38) mengemukakan bahwa fungsi manajemen mencakup 1) perencanaan, 2) pengorganisasian, 3) pemotivasian, 4) pengawasan, dan 5) penilaian. Menurut Hansen dan Mowen (1996) sebagaimana dikutip oleh Abidin (2015: 121) menjelaskan bahwa manajemen adalah proses penetapan standar dengan menerima umpan balik berupa kinerja yang sesungguhnya dan mengambil tindakan yang diperlukan jika kinerja tersebut berbeda secara signifikan dengan hal-hal yang telah direncanakan sebelumnya.

Kajian yang relevan atau mirip dengan penelitian ini memiliki karakteristik yang membedakan antara penelitan tersebut dengan penelitian tentang sistem manajemen komunikasi komunikasi yang akan dilakukan ini. Sebagai upaya untuk mengungkapkan orisinilitas kajian yang akan dilakukan ini, maka akan dipaparkan satu satunya penelitian yang telah dilakukan dengan penelitian terkait yang penulis 
temukan dalm journal ilmu dakwah UIN Sunan Gunung Djati Bandung. Penelitian lain yang menjadikan masjid sebagai objek penelitiannya adalah sebagaimana berikut: Ruhiyat (2015) tenang manajemen dakwah berbasis masjid pada masyarakat transisi, Ahmad Setiawan (2017) mengatakan saat ini terjadi pergeseran paradiga dakwah dari tradisional ke media sosial. Febyanti Nur Fitriani (2014) menyatakan bahwa saat ini masjid akan lebih hidup oleh remaja.

Kemudian beberapa jurnal yang mengkaji tentang media dalam dakwah adalah Khoiro Ummatin (2018) yang memandang bahwa tuntutan globalisasi komunikasi menimbulkan tuntutan dakwah bermedia. Japarudin (2012) membahas tentang urgensi media massa yang tinggigi untuk kepentingan dakwah. Mohammad Zamroni. (2009) menyatakan bahwa perkembangan teknologi komunikasi saat ini dapat mempengaruhi kehidupan. Kemudian Juniawati (2014) menyatakan bahwa dakwah melalui media elektronik sangat berperan penting di Kalimantan Barat. Berdasarkan tinjauan pustaka tersebut, penelitian ini dapat menambahkan dan mengembangkan kajian dakwah melalui media sosial khususnya melalui instagram di salah satu masjid kawasan yang terkenal di kota Bandung yaitu masjid Trans Studio Bandung.

Kata komunikasi atau communication dalam bahasa inggris berasal dari bahasa latin communis yang artinya sama, communico, communication, atau communicare yang berarti membuat sama (to make common). Istilah pertama (communis) adalah istilah yang paling sering sebagai asal usul kata komunikasi, yang merupakan akar dari kata-kata Latin lainnya yang mirip. Komunikasi menyarankan bahwa suatu pikiran, suatu makna, atau suatu pesan dianut secara sama (Mulyana, 2005: 4). Menurut Aliyudin (2010: 194) "Metode dakwah merupakan salah satu unsur dakwah yang memiliki peran penting dan strategis untuk keberhasilan dakwah". Strategi ini dibagi menjadi dua; reduksi formal dan reduksi fungsional (Tohari, 2019: 86).

Pengertian komunikasi menurut Berelson dan Starainer yang dikutip oleh Fisher dalam bukunya Teori-Teori Komunikasi adalah penyampaian informasi, ide, emosi, keterampilan, dan seterusnya melalui penggunaan simbol, kata, angka, grafik dan lain-lain (Fisher, 1990: 10).

Sedangkan menurut Effendy (1984) Komunikasi adalah peristiwa penyampaian ide manusia. Dari pengertian ini dapat disimpulkan bahwa komunikasi merupakan suatu proses penyampaian pesan yang dapat berupa pesan informasi, ide, emosi, keterampilan dan sebagainya melalui simbol atau lambang yang dapat menimbulkan efek berupa tingkah laku yang dilakukan dengan mediamedia tertentu (Effendy, 1984: 6).

Paradigma Lasswell di atas menunjukkan bahwa komunikasi meliputi lima unsur sebagai jawaban dari pertanyaan yang diajukan itu, yakni: a) Pengirim Pesan atau Komunikator (Communicator, Source, sender); b) Pesan (message); c) Media (channel); d) Penerima Pesan atau Komunikan (Communicant, Communicate, Receiver, Recipient); e) Efek atau Umpan Balik (Effect, Impact, Influence, Feedback). 
Teori Ekologi Media adalah teori yang menjadikan media membentuk dan mengorganisasikan sebuah budaya, teori ini membahas mengenai lingkungan media, ide dan teknik, cara penyampaian informasi, dan kode komunikasi memainkan peran utama dalam kehidupan manusia (West \& Turner, 2008: 137 153). Menurut Mc Luhan mengatakan bahwa ekologi media berarti menyusun beberapa media yang beragam guna membantu sesama sehingga mereka tidak mau untuk keluar dari rangkaian tersebut atau tatanan yang telah terbentuk tersebut, karena pada hakikatnya mereka saling menunjang satu sama lainnya.

Dulwahab (2010: 23) berpendapat bahwa Fenomena yang sering disebut sebagai konvergensi media ini memunculkan beberapa kemajuan penting. Misalnya, radio mungkin memiliki peranan yang lebih besar daripada televisi dalam membantu kita dalam hal yang berhubungan dengan kemampuan literasi, akan tetapi televisi mungkin juga memberikan bantuan yang sangat besar dalam mengajarkan kita tentang masalah kebahasaan (West \& Turner, 2008: 137-153). Teori Ekologi Media dikenal karena slogan: medium adalah pesan. Frase tersebut merujuk pada kekuatan dan pengaruh medium terhadap masyarakat, bukan isi pesannya. Medium mampu mengubah bagaimana kita berpikir mengenai orang lain, diri kita sendiri, dan dunia di sekeliling kita. Akan tetapi Mc Luhan tidak mengesampingkan pentingnya isi.

Mc Luhan merasa bahwa isi mendapatkan perhatian lebih dari kita dibandingkan dengan yang didapat medium. Walaupun sebuah pesan mempengaruhi keadaan sadar kita, medium lebih besar mempengaruhi keadaan bawah sadar kita (West \& Turner, 2008: 138-154). Pengaruh teknologi media terhadap masyarakat merupakan gagasan utama dari teori ekologi media (Ardianto, 2011: 18). Tema-tema yang dibahas dalam Teori Ekologi Media mencakup beberapa bidang, yaitu kekuasaan dan ketidaksetaraan, integrasi sosial dan identitas, dan perubahan sosial dan pembangunan. Dengan putranya, Eric Mc Luhan, Mc Luhan mengembangkan sebuah cara untuk melihat lebih jauh ke dalam efek teknologi terhadap masyarakat. Perluasan teorinya mencakup hukum media. Hukum media adalah perluasan lebih jauh dari Teori Ekologi Media dengan fokus pada dampak teknologi terhadap masyarakat.

Perkembangan komunikasi akhir-akhir ini, terutama secara teknologi tidak pernah ada satu garis perkembangan yang tunggal. Kendati label-label imbuhan seperti Era Digital mungkin ada gunanya dan membuka pikiran kita terhadap fenomena masa lampau dan masa kini. Ciri utamanya adalah kompleksitas. Kata cyberpace (ruang maya) pertama kali digunakan oleh seorang penulis fiksi ilmiah, William Gibson. Seorang cybernot (penjelajah ruang maya) dapat melihat dan bergerak bebas menelusuri dunia maya. Ruang maya tidak seperti televisi tetapi mirip sebuah bacaan yang tidak disensor, tidak dijaga oleh penjaga pintu, namun ia tidak dapat melarikan diri dari akumulasi sejarah.

Ketika Silicon Graphics pelopor perusahaan maya menemukan sistem komputer berbasis pada apa yang disebut reality engines, yang dirancang supaya memompa keluar informasi memori dan menjaga ilusi agar tetap hidup. Sistem 
komputer tersebut adalah internet (Oetomo, 2006: 393). Internet merupakan teknologi yang menyimpan segudang fasilitas dan layanan yang patut dipahami dan dikuasai oleh siapa pun di zaman modern. Namun internet bagaikan hutan rimba. Penjelajah yang belum berpengalaman tentu membutuhkan peta dan pemahaman baik konsep maupun teknis aksesnya agar tidak tersesat dan dapat menikmati kegiatan penjelajahan (Oetomo, 2006: 32).

Interaktivitas yang ditewarkan dalam proses komunikasi di internet membuat setiap orang bebas tampil dengan identitas masing-masing. Meskipun interaksi di internet memiliki banyak sisi positif, tetapi ditemukan juga bahwa ada beberapa efek negatif terhadap hubungan antar personal jika pengguna lebih memilih untuk menghabiskan waktu lebih banyak di dunia maya. Salah satunya adalah yang disebutkan oleh psikiater, Edward Hallowell sebagai kurangnya momen manusia. Menurut Hallowell, ada dua syarat mutlak untuk terjadinya momen manusia, yaitu harus adanya kehadiran secara fisik dan perhatian emosional serta intelektual. Kedua syarat ini diperlukan untuk menjaga aktifitas mental dan jugakesehtan emosonal (Ardianto, 2011: 144).

Mengacu kepada pendapat Terry yang dikutip oleh Syafaruddin bahwa "management is performance of conceiving desired results by means of group efforts consisting of utilizing buman talent and resources". Ini dapat dipahami bahwa manajemen adalah kemampuan mengarahkan dan mencapai hasil yang diinginkan dengan pemberdayaan manusia dan sumber daya lainnya (Syafaruddin, 2005: 41). Dari pendapat tersebut dapat dipahami bahwa manajemen adalah kekuatan utama dalam sebuah organisasi yang mengkoordinasikan berbagai kegiatan serta berhubungan dengan lingkungannya. Menurut Made Pidarta dalam bukunya Manajemen Pendidikan Islam, menjelaskan bahwa; Manajemen ialah proses mengintegrasikan sumber-sumber yang tidak berhubungan menjadi sistem total untuk menyelesaikan suatu tujuan (Pidarta, 1989: 41).

Menurut Marsetio Donosepoetro dalam proses komunikasi ada beberapa ketentuan, antara lain 1) Karena komunikasi mempunyai suatu maksud, maka suatu message atau stimulus selalu ditujukan kepada sekumpulan orang tertentu. Ini disebut penerima yang tertentu; 2) Komunikator berkeinginan menimbulkan suatu respon kepada penerima yang sesuai dengan maksud yang dibawakan oleh message atau stimulus tertentu; 3) Suatu komunikasi dinyatakan berhasil jika respon yang timbul pada penerima, sesuai dengan maksud komunikasi (Donosepoetro, 1982: 37). Demikian juga dalam dakwah, menurut Tarwiah dan Fatoni (2016: 102) penggunaan bahasa yang dimengerti oleh netizen, memudahkan netizen membaca pesan dengan baik sampai masuk ke dalam hati mereka.

Berdasarkan fakta keberhasilan DKM mendatangkan ribuan jamaah dengan konsep manajemen tersebut, maka tujuan penelitian ini adalah untuk mengetahui 1) planing (perencanaan), 2) orgnaizing (pengorganisasian), 3) actuating (pelaksanaan), dan controlling (pengawasan) kegiatan publikasi informasi kajian yang dilakukan oleh DKM masjid Trans Studio Bandung. Metode Penelitian yang digunakan 
dalam penelitian ini adalah metode Deskriptif, dan pendekatan manajemen Komunikasi. Sedangkan teknik pengumpulan data yang digunakan dalam penelitian ini adalah teknik observasi, dokumentasi, dan wawancara.

\section{HASIL DAN PEMBAHASAN}

Masjid Agung Trans Studio Bandung didedikasikan untuk ibunda Bapak Chairul Tanjung. Masjid ini mulai digunakan untuk shalat 5 waktu dan tarwih sebulan penuh. Akhirnya, bertepatan pada hari Jum'at tanggal 10 Jui 2015 Masjid Agung Trans Studio Bandung di resmikan langsung oleh Chairul Tanjung di Kawasan Terpadu Trans Studio Bandung yang juga di hadiri oleh Gubernur Provinsi Jawa Barat Ahmad Heryawan.

Visi dari didirikannya masjid ini adalah 1) Menjadi salah satu pusat ibadah, dakwah dan pendidikan Islam yang representatif, nyaman, akomodatif, favorit dan kontributif di Kota Bandung. 2) Menjadi fasilitator edukasi, komunikasi, dan sinergi untuk SDM strategis dan profesional umat Islam Indonesia. 3) Menjadi organizer acara silaturahim sinergi dan moderator dialog solusi antar potensi umat.

Ada pun dengan misi masjid Tras Studio Mall ini adalah 1) Berkhidmat melayani umat dalam hal ibadah dan pendidikan Islam. 2) Berkontribusi pada pengembangan kualitas SDM dan masyarakat muslim. 3) Berkontribusi pada pengembangan kualitas SDM dakwah dan pendidikan Islam. 4) Berkontribusi pada penguatan dan pembangunan ketahanan keluarga Indonesia. 5) Berkontribusi pada terwujudnya sinergi dan persatuan umat Islam Indonesia. 7) Berkontribusi pada pembangunan kualitas SDM remaja dan pemuda muslim Indonesia. 8) Berkontribusi pada pemberdayaan yatama, masakun dan dhuafa melalui optimasi dana infaq. Untuk dapat mencapai visi dan misi tersebut, maka manajemen komunikasi pada publikasi kegiatan sangat penting dilakukan.

\section{Perencanaan Publikasi Kegiatan di Masjid Agung Trans Studio Bandung}

Kegiatan kajian yang secara internal diselenggarakan dan direncanakan oleh DKM masjid merupakan kegiatan kajian Islam yang terbuka untuk umum. Tidak hanya itu, Masid Agung Trans Studio Bandung juga mempunyai kegiatan eksternal dari Mitra Ta'lim. Ketua DKM Masjid Agung Trans Studio Bandung bapak Nazarudin mengungkapkan bahwa persiapan rencana publikasi kegiatan internal dan eksternal sama sebagai mana pernyataan berikut:

yah sebetulnya tidak ada bedanya yah, kajian yang diselenggarakan DKM ataupun yang diselenggarakan dengan bekerjasam dengan Mitra Ta'lim pun itu itu juga yang dilakukan. Seperti dengan komunitas pemuda hijrah, shaf muslimah, hijabers community dan mitra ta'lim lainnya. Kami menyerahkan persiapan publikasi informasi kajian-kajian tersebut kepada tim HUMAS khususnya pak Jajat yang bertanggungjawab atas media sosial. (Hasil wawancara dengan Ketua DKM Masjid Agung Trans Studioo Bandung Ir. 
Budi Nazarudin. Beliau juga merupakan Manager Propetindo dari PT. ParaBandung di kantor DKM pada hari Senin 5 Maret 2018 di kantor ketua DKM pada pukul 13.05 WIB)

Mitra Ta'lim merupakan sekumpulan masyarakat yang mengadakan pengajian atau kegiatan apapun di Masjid Agung Trasn Studio Bandung. Karena sejauh ini, dari pihak masjid belum mempunyai kegiatan rutin untuk kajian yang di sajikan kepada para jama'ah. Maka dari itu, pihak masjid selama ini selalu menerima kegiatan-kegiatan yang diadakan oleh kelompok tertentu (Majelis Ta'lim) agar bisa mengadakan pertemuan atau kajian kajian yang di adakan oleh kelompok tersebut. Perbedaan publikasi kegiatan yang dilakukan oleh DKM secara internal dan kegiatan yang bersinergi dengan mitra ta'lim adalah logo. Kegiatan yang diselenggarakan oleh internal DKM hanya mencantumkan logo DKM saja, adapun dengan kegiatan yang bersinergi dengan mitra ta'lim terdapat logo komunitas yang mengandakan kegiatan dan logo-logo sponsor yang mendukung kegiatan tersebut.

Memang seperti terlihat sama ya teh, tapi sebetulnya gampang banget buat ngebedain mana kegiatan yang diselenggarakan oleh DKM dan mana yang diselenggarakan dengan bersinergi dengan mitra ta'lim. Nah coba liat ini, (menunjukan hasil-hasil postingan informasi kegiatan melalui akun instagramnya) nah jdulnya Temani Aku (bantu temanmu berhijrah) diatasnya ada logo dan nama komunitas pejuang mahar, dan dibawahnya ada promot akun IG-nya, poster kajian yang diposting pada 2 Maret ini dibuat oleh mereka, jadi kami hanya mencantumkan logo DKM saja di bawahnya. Nah kalau ini murni kegiatan kajian yang diadakan DKM (menunjukan postingan 22 Febuari kajian Kugadaikan Dunia oleh ustadz Rahmat Baequni) disini tiadak ada logo komunitas manapun hanya logo kami saja dan ada promot IG-nya, ada pun dengan logo suport yang dibawah itu adalah logo-logo keluarga trans juga hehe. (Hasil wawancara dengan bapak Jajat Eka O Gunawan bidang Humas yang bertanggungjawab atas Media Sosial dan publikasi kegiatan pada hari Senin 5 Maret 2018 di kantor ketua DKM pada pukul 15.10 WIB).

Berdasarkan pernyataan dari bapak Jajat tersebut, maka telah jelas bahwa poster kegiatan yang dipublikasikan terdapat perbedaan. Kajian Islam yang diselenggarakan oleh mitra Ta'lim memiliki identitas dari mitra ta'lim tesebut yang menyelenggarakannya, sedangankan kajian yang diadakan oleh internal DKM tidak ada logo lain selain logo DKM dan grup-grup Transcrops. Berikut ini salah satu contoh poster yang telah dipublikasikan melalui akun instagram (a)masjidtras_: 


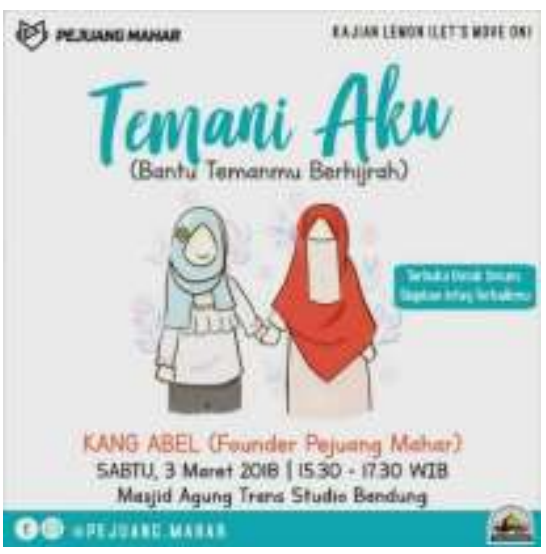

Gambar 1. Contoh poster publikasi kegiatan kajian dari mitra ta'lim

Dalam merencanakan publikasi kegiatan, DKM masjid Agung Trans Studio Bandung telah melakukan manajemen yang baik, hal ini sejalan dengan pernyataan yang diungkapkan bapak Jajat saat diwawancara:

Untuk share info-info kajian atau kegiatan lainnya yang bertempat di masjid TSM ini, memang kami tidang terlalu melibatkan banyak orang, namun kami melakukan tugas sesuai dengan porsi masing-masing, misalnya pak Indra yang melakukan penjadwalan waktu dan konfirmasi pengisi kajian, kalau saya yang ngurus medsosnya. Paling lambat H-3 sih kami upayakan setiap kegiatan sudah terpublikasikan. Nah kalau misalnya ada mitra Ta'lim yang tidak bisa membuat poster untuk bahan publikasi di medsos di kami ada bapak Dadang Sopandi sebagai Desain Grafis. (Hasil wawancara dengan ketua bidang Humasis spesialis Media Sosial Bpak Jajat Eka O Gunawan pada hari Senin 5 Maret 2018 di kantor ketua DKM pada pukul 14.45 WIB). Merencanakan sebuah kegiatan kajian, DKM masjid Trans Studio Bandung ini sangat bertahti-hati dalam melakukannya. Untuk mengantisipasi terbenturnya dua kegiatan maka secara jelas ketua DKM menjelaskan:

klo perencanaan itu karena banyak partisipan dari majelis ta'lim yang mengajukan kegiatan. Kita hanya meng-schedule-kan saja. Pertama kita lihat ustad yang mengisi, kalau ustadnya besar atau yang dikenal masyarakat dan diperkirakan akan banyak yang hadir, nanti perlu adanya kita meeting bagaimna kita mengorganisir secara oprasionalnya dengan yang lain. (Hasil wawancara dengan ketua DKM bapak Budi Nazarudin pada hari Senin 5 Maret 2018 di kantor ketua DKM pada pukul 13.25 WIB)

Bentuk komunikasi eksternal yang digunakan oleh DKM masjid Agung Trans Studio Bandung antara lain adalah rapat, laporan, memo, dan lain-lain. Untuk komunikasi internal dilakukan kepada anggota yang terdapat dalam organisasi proyek. Menentukan tema kegiatan tentu tidaklah mudah, dari berbagai kegiatan yang terdapat di masjid Agung Trans Studio Bandung ini, DKM bekerjasama dengan berbabagai mitra ta'limnya dalam menentukan tema-tema 
kajian. Dapat dikatakan bahwa masjid Agung Trans Studio Bandung hanya penyedia tempat saja bagi kebanyakan kegiatan kajian. Berbeda dengan kajian, kutbah jumat yang telah dirumuskan satu tahun sebelumnya dibuat berdasarkan kredibilitas khatib tersebut, begitu pun dengan penentuan tema khutbahnya. Berikut ini komentar dari ketua DKM masjid Agung Trans Studio Bandung tentang khatib jumat:

oh, mungkin itu dari segi keilmuannya, kemudian kedua yang sudah dikenal. Kan klo khutbah jumat harus ada sesuatu yang membuat fokus jadi dari segi materi dan da'inya harus sesuatu yang cukup menarik perhatian. (Hasil wawancara ketua DKM bapak Budi Nazarudin Senin 5 Maret 2018).

Tema dari berbagai kegiatan baiasanya disesuaikan dengan kondisi dan waktu. Dalam beberapa kajian, setiap mitra ta'lim memiliki tema dan pengisi kajiannya masing-masing. Syarat dan ketentuan untuk menyelenggarakan kegiatan di masjid ini pun tidak ada ketentuan yang sulit dan khusus, dengan kata lain apabila tidak berbenturan dengan kegiatan ta'lim lainya jamaah diperbolehkan melakukan kegiatan di dalam masjid. Berikut ini penjelasan dari ketua DKM tentang syarat dan ketentuan untuk menyelenggarakan kegiatan:

Tidak ada, tapi saya melihat potensinya. Meskipun bermacam-macam Ustadkan dan belum tentu dia lulusan sekolah keagamaan. Tetapi melihat adanya perbedaan, ciri khas yang membedakan dengan ustad-ustad yang lain. Dan jika ada kolaborasi antara ustad yang satu dengan ustad yang lain maka keilmuannya pun bagus untuk memberikan ilmu yang baru kepada jamaah. Disamping untuk menghindari monotisitas. Seperti itu pola dan strategi seperti itu harus kita kasih tau juga. (Hasil wawancara dengan ketua DKM bapak Budi Nazarudin pada hari Senin 5 Maret 2018 di kantor ketua DKM pada pukul 13.25 WIB).

\section{Pengorganisasian Publikasi Kegiatan di Masjid Agung Trans Studio Bandung}

Pengorganisasian publikasi kegiatan terdiri dari bapak Indra Arlianto dan bapak Wahyu Lesmono yang berhubungan secara personal dengan ketua-ketua mitra ta'lim, bapak Jajat Eka O. Gunawan yang dibatu oleh staf IT dan media yaitu Windi N. Fadilah dan M. Faris Al-Aziz serta Dadang Sopandi sebagi desainer grafis (Hasil dari studi Dokumen struktur Organisasi DKM Masjid Agung Trans Studio Bandung pada kalender tahun 2018 halaman 2).

Saya Jajat dibagian humas bidang media, pak indra humas bagian hubungan eksternal dan pakwahyu humas bagian penjadwalan kegiatan masjid. Khisus desainer ada pak dadang, pak Windi sama pak Faris Bidang IT merangkap desain (Hasil wawancara dengan ketua bidang Humas Jajat Eka O Gunawan pada hari Senin 5 Maret 2018 di kantor ketua DKM pada pukul 14.50 WIB). Berdasarkan hasil wawanara dengan beberapa jama'ah, dapat disimpulkan bahwa dari kegiatan yang disajikan tersebut banyak jama'ah yang menyatakan suka 
dan selalu mengikuti kajian tersebut dengan rutin dan serius. Karena menurut mereka, dengan mengikui kajian kajian seperti itu bisa memberikan suatu motivasi beribadah yang lebih baik dari sebelumnya. Berdasarkan informasi dari bidang humas bahwa jamah menyatakan merasa nyaman dengan fasilitas fisik yang terdapat di masjid Agung Trans Studio Bandung mulai dari karpet yang nyaman, AC yang sejuk pengharum ruangan yang wangi dan lain sebagainya. Fasilitas kenyamanan ini adalah hasil dari pola komunikasi yang dilakukan oleh DKM masjid Agung Trans Studio Bandung sebagaimana diungkapkan oleh bidang pemeliharaan dan perlengkapan:

Yaah yang namanya juga tempat wudhu dan WC kalau bau-bau pesing sedikit mah wajarlah, tapi kami selalu berusaha untuk mengantisipasi hal tersebut. Agar tidak kotor ada petugas yang stand by untuk secara langsung membersihkan dan memberikan pewangi lantai. Jadi kalau komunikasinya mah lewat saya yang pegang $H T$ dan sayang yang keliling ke semua wilayah buat ngontrol dan sekalian bantu-bantu kerja juga. (Hasil wawancara dengan bapak Arif Rakhman ketua bidang pemeliharaan dan peralatan di kantor DKM PUSDATA lantai 2 masjid pada hari Jumat, 13 April 2018 pukul 14.00).

Dari beberapa kegiatan yang diadakan oleh Mitra Ta'lim, terlihat para jama'ah mendengarkan dengan baik kajian-kajian tersebut. Terlebih lagi apabila pengisi kajian tersebut merupakan muballigh yang terkenal. Biasanya jama'ah akan lebih banyak dan jama'ah pun terlihat lebih serius mendengarkan kajian tersebut. Biasanya, waktu yang dilaksanakan untuk melaksanakan kajian tersebut dari jam 09.00 sapai $11.00 \mathrm{WIB}$.

Dari data di atas, dapat di analisis bahwa dari khitobah yang di sajikan dengan kajian-kajian setiap minggunya bahwa para jamaah sangat antusia untuk mengikuti kajian tersebut. Dan dapat di tafsirkan, bahwa para jamaah antusias mengikuti kajian-kajian yang di sajikan oleh Mitra Ta'lim yang bertepatan di Masjid Agung Trans Studio Bandung. Dan kajian ini juga secara tidak langsung memberikan motivasi bagi para jamaah untuk lebih baik lagi dalam menjalankan ibadah.

Selain melalui instagram, pengurus juga memiliki channel Youtube yang bernama Masjid Agung Trans Studio Bandung. YouTube adalah sebuah situs web berbagi video yang memungkinkan pengguna mengunggah, menonton, dan berbagi video. Media, media kita didukung oleh jaringan-jaringan sosial yang selalu kita kembangkan dan berusaha di update terus. Kemudian kita komunikasikan juga dengan jaringan-jaringan media sosial majelis ta'lim lainnya.( Hasil wawancara dengan bapak Jajat Eka O Gunawan bidang Humas yang bertanggungjawab atas Media Sosial dan publikasi kegiatan pada hari Senin 5 Maret 2018 di kantor ketua DKM pada pukul 15.00 WIB).

Di website ini, kita bisa menyaksikan muballigh yang menyampaikan ajaranajaran Islam dengan media audio visual. Bukan hanya sekedar menulis dan berbicara di atas mimbar, kegiatan tabligh yang di laksanakan oleh pengurus DKM 
Masjid Agung Trans Studio Bandung juga melalui on camera atau di depan kamera yang langsung di upload atau di unggah di channel YouTube. orang-orang pun di sedikit yang menonton video tersebut. secara tidak langsung, video yang ada di YouTube itu sudah menyiarkan ajaran-ajaran Islam.

\section{Pelaksanaan Publikasi Kegiatan di Masjid Agung Trans Studio Bandung}

Masjid bagi umat Islam merupakan kebutuhan mutlak yang harus ada sejak awal sejarahnya masjid merupakan pusat segala kegiatan masyarakat Islam. Sehingga masjid menjadi point of development. Berbagai kekuatan yang mempengaruhi fungsi masjid sebagai pusat umat Islam sadar atau tidak berlangsung terus mulai dari penciutan fungsinya yang hanya sebagai pusat ibadah sampai mulai berkembang pada saat ini dimana terlihat ada kecenderungan gerakan baru di kalangan umat untuk lebih mengoptimalkan fungsi masjid. Hal ini sebagaimana yang telah dilakukan oleh DKM masjid Trans Studio Bandung yang berusaha memberikan fasilitas dan kenyamanan terbaik untuk memberikan fungsi masjid seperti seharusnya. Bapak Jajat yang memegang kendali atas media sosial menuturkan:

pengelolaan media sosial di awal tahun 2017, tepatnya di bulan April. Dari kita mulai menyadari bahwa media sosial sangat penting. Di awal akun media yang bergerak di facebook, instagram dan youtube sudah ada, termasuk line dan juga telegram terus website. Untuk strategi tidak secara gambling seperti sebuah perusahaan, namun secara maping ada beberapa target yang harus dicapai seperti awal bulan apa, pertengan begitupun dengan akhir bulan apa. Pada alawalnya publikasi kegiatan melalui facebook dan intagram, akun youtube sudah ada cuan kendala awal kontennya belum dimasukan. Mulai bulan maret-april 2017, mulailah konten-konten kegiatan dipublikasikan melalui youtube (Hasil wawancara dengan ketua bidang Humasis spesialis Media Sosial Bpak Jajat Eka O Gunawan pada hari Senin 5 Maret 2018 di kantor ketua DKM pada pukul 14.50 WIB).

Dari dahulu sampai saat ini masjid bukan saja sebaga sebagai tempat shalat saja, tetapi juga sebagai tempat untuk memberikan pendididikan agama dan umum, rapat-rapat organisasi, pertokoan, dan bahkan kegiatan pernikahan. Perkembangan pada zaman ini sangat terasa di kawasan elit. Dengan adanya fenomena ini, bagaimana sebaikanya masjid dikelola dengan sebaik-baiknya sehingga investasi yang demikian besar itu dapat memberikan manfaat yang sebesar-besarnya kepada umat Islam. Seperti jakian-kajian keIslaman, musyawarah dan berbagai macam kegiatan lainnya.

Masjid memiliki peran penting pada zaman Rasulullah SAW sampai saat ini. Sejak periode Nabi Muhammad masih dipandang sebagai pusat utama bagi aktivitas masyarakat muslim. Kehadiran Masjid Agung Trans Studio Bandung di kawasan pusat perbelanjaan itu sendiri mempunyai daya tari bagi masyarakat sekitar khususnya bagi para pengunjung Mall. Karena dengan adanya sebuah masjid megah di kawasan pusat perbelanjaan secara tidak langsung memiliki daya 
Tarik tersendiri untuk mendatangi masjid tersebut. Terlebih lagi dengan arsitektur yang sangat megah membuat semua orang yang melihat takjub akan masjid tersebut. DKM masjid Trans Studio Bandung senantiasa berusaha untuk memberikan kenyamanan kepada jamaah bagi yang ingin beribadah atau pun melakukan kegiatan di dalamnya. Salah satunya adalah tentang penjadwalan imam dan khatib jumat sebagaimana diungkapkan oleh ketua DKM berikut:

pernah ada khatib yang berhalangan hadir mendadak. Cara kami mengatasinya adalah dengan badal khatib. ada ustad badal, yang diatur oleh timnya PUSDATA (pusat dakwah dan ta'mir) yang tugasnya lebih banyak mengatur kepada ibadah harian seperti: solat, dan ibadah rutin lainnya. Dan klo tugas oprasional lainnya dari kita ya pengurus (Hasil wawancara dengan ketua DKM bapak Budi Nazarudin pada hari Senin 5 Maret 2018 di kantor ketua DKM pada pukul 13.25 WIB).

Dari segi keseragaman pengurus DKM masjid Trans Studio Bandung ini dapat mengangkat derajat seorang marbot yang kebanyakan dipandang rendah banyak orang. Berikut ini penjelasan seragam pengurus :

seragam merah, marbot. Klo kita pengurus tidak ada seragam cuman seragam karyawan saja. Dan klo ustad ada seragammnya di atas saku ada name tag nama dan logo Masjid Agung Trans Studio Bandung kalau ustad pake jas ada seragamnya lagi. Ada pun dengan ustad yang terdata disini direkrut, mereka juga ganting dari mulai imam solat, membadal solat dan mereka juga memberikan pengumuman.

Majelis Ta'lim dapat disebut lembaga pendidikan non formal Islam, yang senanstiasa menanamkan akhlak yang luhut dan mulia serta meningkatkan kemajuan ilmu pengetahuan dan keterampilan jamaahnya. Sebagai lembaga pendidikan non formal, majelis ta'lis memiliki karakteristik sendiri yang diantaranya pengajian dilaksanakan secara berkala dan teratur dengan diikuti oleh jamaah yang relative banyak. Di masjid Trans Studio Bandung ini terdapat banyak masjis taklim yang secara rutin menyelenggarakan kegiatan ta'lim. Baik dari golongan muda, dewasa, bahkan golongan tua.

Karena daya tarik itupun, akhirnya banyak sekali yang datang ke Masjid Agung Trans Studio Bandung umtuk melihat bagaimana kemegahan dari masjid tersebut. Selain karena adanya mall dan wahana bermain, Trans Studio juga menyediakan sarana dan prasarana yang ditunjukan untuk perbadatan umat Islam. Menariknya, masjid ini merupakan satu-satu masjid yang megah dan tempat nya berada di kawasan pusat perbelanjaan dan tempat wahana bermain di kota Bandung. Sehingga tidak sedikit yang datang ke sana bukan untuk berbelanja akan tetapi untuk mengikuti kegiatan keberagamaan di Masjid Agung Trans Studio Bandung.

Selama 2 tahun terakhir ini, banyak sekali para jama'h yang datang ke Masjid Agung Trans Studio Bandung untuk mengahadiri pengajian yang di adakan oleh majelis ta'lim yang menjadi Mitra Ta'lim. Mitra Ta'lim merupakan kumpulan dari kelompok pengajian atau majelis ta'lim dari berbagai tempat yang menggunakan 
Masjid Agung Trans Studio Bandung menjadi tempat untuk melaksanakan kegiatan keagamaan Islam seperti pengajian atau tabligh akbar. Sejauh ini, 90\% kegiatan yang dilaksanakan di Masjid Agung Trans Studio Bandung diadakan oleh Mitra Ta'lim. Mengapa demikian? Karena para jamaah ingin melaksanakan pengajian tersebut di Masjid Agung Trans Studio Bandung. Selain mempunyai daya tarik sendiri karena kemegahan masjid tersebut, para jamaah pun merasa bahwa masjid ini merupakan menjadi barometer, maksudnya adalah masjid ini sudah menjadi pusat ibadah di daerah Bandung Timur sehingga banyak sekali jamaah yang datang ke masjid terebut dari wilayah Bandung Timur (Hasil wawancara dengan Ketua DKM Masjid Agung Trans Studioo Bandung Ir. Budi Nazarudin di kantor DKM pada hari Senin 5 Maret 2018 di kantor ketua DKM pada pukul 13.09 WIB)

Mitra Ta'lim yang bekerjasama dengan DKM dari Masjid Agung Trans Studio Bandung terhitung banyak, karena masjid ini merupakan masjid central yang dimana letak dari masjd ini sangat strategis. Ada beberapa Mitra Ta'lim yang penulis temui yaitu Majelis Ta'lim Rumahku Surgaku yang di gagas oleh Bunda Linda. Beliau merupakan sosok yang sangat penting bagi keberlangsungan dakwah khususnya di Masjid Agung Trans Studio Bandung. Beliau juga merupakan penggerak komunitas-komunitas Islam seperti Mujahadah Community, Majelis Ba'rul Akhirat, Pejuang Al-Qur'an, Hijab Comunity dan masih banyak lagi tambah bapak Indra saat diwawancara.

\section{Pengawasan Publikasi Kegiatan di Masjid Agung Trans Studio Bandung}

Pengawasan merupakan suatu tahapan yang dilaksanakan untuk menentukan atau memperlihatkan nilai suatu program termasuk pengelolaan maupun hasil atau dampak pelaksanaannya. Melalui Pengawasan, bidang Humas masjid Agung Trans Studio Bandung akan mengetahui faktor-faktor yang menjadi kegagalan ataupun keberhasilan suatu program, sehingga dapat ditentukan langkah-langkah selanjutnya yang seharusnya dilakukan. Dalam media publikasi melalui media sosial tentu DKM Masjid Trans Studio Bandung tidak hanya melakukan publikasi semata, namun juga melakukan Pengawasan atas publikasi yang dilakukan. Penanggungjawab media sosial DKM Masjid Trans Studio Bandung bapak Jajat mengungkapkan:

Untuk media sosial ataw online itu murah namun kita harus bias memilah memilih konten semenarik mungkin. Yang paling penting sih storytelling nya bagus, jamaahnya respek dan disinilah pihak humas harus siap menerima keluhan jamaah seperti tempat wudhhu yang kurang nyaman atau keluhan lainnya (Hasil wawancara dengan ketua DKM bapak Jajat bidang Humas divisi media sosial pada hari Senin 5 Maret 2018 di kantor ketua DKM pada pukul 14.59 WIB).

Bentuk Pengawasan yang dilakukan oleh bidang humas ini adalah dengan ngobrol santai ngobrol santai pasca solat berjamaah dan baca quran ini sangat 
efektif dilakukan ujar bapak Jajat. Karena bidang Humas hanya ada 3 orang maka biasanya setelah solat berjamaah dzuhur atau ashar kami selalu ngariung membicarakan kegiatan-kegiatan yang sedang, akan atau telah dilaksanakan tambah bapak Imam.

Kalu emang bener-bener urgen kami upayakan berkumpul semua, biasanya sih bada solat ashar, yaaa stelah dzikir dan tadarus al-quran-lah baru kita ngariung gitu. Intinya mah kami ga formal-formal banget yah, ngobrol serius efektif tapi pembawaann dan suasananya santei, kurang lebih gitu teh (Hasil wawancara dengan ketua DKM bapak Jajat bidang Humas divisi media sosial pada hari Senin 5 Maret 2018 di kantor ketua DKM pada pukul 15.00 WIB).

Selain itu inprogress monitoring ini juga berguna untuk menjelaskan alasan mengapa sebuah program bisa berjalan tidak sesuai dengan tujuan awal. Sebagaimana beberapa kendala yang pernah terjadi pada tahap publikasi tentang persiapan poster dan waktu yang relative sempit untuk mempublikasikan kegiatan, maka DKM masjid Agung Trans Studio Bandung pun berusaha untuk memodifikasi proses publikasi yang dianggap kurang tepat.

Netizen itu kan biasanya sensitive dan selalu ingin diperhatikan. Nah ketika ada yang komen dan kita hanya jawab iya blablabla mereka udah, jadi yang terpenting mereka pengen diperghatikan dan pengen didengar. Kendalanya adalah saat kita posting poster yang mendadak, maksimal H-1 baru diposting dan ada beberapa netizen yang menyayangkan gitu, karena beberapa jamaah selalu ada yang dari luar kota bahkan dari luar pulau yang sengaja hanya untuk ikut kajian (Hasil wawancara dengan bapak Jajat Eka O Gunawan bidang Humas spesialis media sosial pada hari Senin 5 Maret 2018 di kantor ketua DKM pada pukul 15.10 WIB).

Dalam konteks publikasi kegiatan yang dilakukan oleh DKM masjid Agung Trans Studio Bandung Pengawasan dilakukan untuk mendorong manajemen yang baik (membuat beberapa tindakan yang dapat dilakukan bila hal buruk yang akan terjadi). Keuntungan-keuntungan yang dihasilkan dari proses Pengawasan tersebut akan mengarahkan praktisi humas pada kesuksesan program.

Tetntu, menurut kami pun Pengawasan sangat penting untuk dilakukan, karena tanpa mengontrol sebuah proses kegiatan menejemen, bisa jadi yang menjadi tujuan dari organisasi bisa melenceng. Makanya kami melakukan Pengawasan pada setiap proses publikasi kegiatan (Hasil wawancara dengan bapak Jajat Eka O Gunawan bidang Humas spesialis media sosial pada hari Senin 5 Maret 2018 di kantor ketua DKM pada pukul 15.15 WIB).

The Equalitarian Style dapat mengungkapkan gagasan ataupun pendapat dalam suasana yang rileks, santai dan informal. Dalam suasana yang demikian, memungkinkan setiap anggota organisasi mencapai kesepakatan dan pengertian bersama. Aspek penting gaya komunikasi ini ialah adanya landasan kesamaan.

Karna kami senang dengan suasana evaluasi yang santai, jadi media-media 
komunikasi yang kami gunakan pun ga terlalu ribet seprti mengharuskan penggunaan spiker dan infocus. Jadi simpel-simpel aja kita mah, kalau ketemu tatap muka bada ashar media yang digunakan hanya lisan saja, kalau memang betul betul urgen, kami menggunakan ruangan DKM yang tertutup biar terhindar dari kebisingan dan setiap orang pasti mencatat point-point bagian masing-masing yang perlu dilakukan, ada yang pake HP ada juga yang pake catetan, kalau saya sih enaknya nyatet langsung (Hasil wawancara dengan bapak Jajat Eka O Gunawan bidang Humas spesialis media sosial pada hari Senin 5 Maret 2018 di kantor ketua DKM pada pukul 15.20 WIB). DKM masjid Agung Trans Studio Bandung senantiasa memperhatikan komunikasi yang baik dan terjalin antara seluruh elemen yang ada. Beberapa kendala yang dirasakan oleh bidang Humas adalah waktu yang terlalu sempit dari mtra ta'lim kepada pembuatan poster dan publikasi media sosial.

Kendalanya sih ada di waktu, kadang suka dikejar-kejar waktu yang mepet. Misalkan harus bikin pamflat tanggal satu harus terpublish. Dalam waktu 2 hari harus bikin pamflat dan besok harinya masksimal harus terpublis. Nah, seletah terjadi kendala-kendala seperti itu, kami melakukan evaluasi. Maka kedepannya agar tidak terjadi lagi hal demikian, pada setiap mitra ta'im yang ingin mengadakan kegiatan di masjid TSM, maka harus betul-betul menentukan waktu yang tidak mendadak (Hasil wawancara dengan bapak Jajat Eka O Gunawan bidang Humas spesialis media sosial pada hari Senin 5 Maret 2018 di kantor ketua DKM pada pukul 15.22 WIB).

Sedangkan karyawan (bawahan) membutuhkan informasi untuk melaksanakan pekerjaan, di samping itu juga informasi tentang jaminan keamanan, jaminan sosial dan kesehatan, izin cuti, dan sebagainya.

Dengan kata lain fleksibelitas waktu yang kami gunakan untuk melakukan Pengawasan ini bisa dibilang mudah dan cukup efektif gitu, karena saat ini kami hanya menerima surat resmi dari komunitas yang ingin menyelenggarakan kegiatan dan menjadwalkan, kemudian nunggu mereka bikin poster selesai, sebelum diposting kita cek dulu kan di WA tuh, nah kalau ada bahasa yang kurang tepat baru kami kritisi dan dikasih saran, soalnya kan kami membawa nama baik DKM juga (Hasil wawancara dengan bapak Jajat Eka O Gunawan bidang Humas spesialis media sosial pada hari Senin 5 Maret 2018 di kantor ketua DKM pada pukul 15.25 WIB).

\section{PENUTUP}

Perencanaan publikasi kegiatan tersebut dilakukan oleh bidang Humas secara komunikatif dan apik serta telah memenuhi standar perencaan yang baik berdasarkan konsep manajemen komunikasi. Perencanaan publikasi kegiatan tersebut meliputi: 1) Pencanangan waktu kegiatan, 2) Penentuan pengisi kajian, 3) Pembuatan tema kegiatan, dan 4) Pembuatan poster kegiatan.

Pengorganisasian untuk publikasi kegiatan yang dilakukan oleh bidang 
Humas DKM masjid Trans Studio Bandung ini sesuai dengan tugas pokok dan fungsi manajerial DKM. Perngorganisasian publikasi kegiatan tidak melibatkan banyak orang namun efektif dan konsisten dilakukan. Pengorganisasian untuk kepentingan publikasi kegiatan ini dilakukan oleh bapak Indra Arlianto dan bapak Wahyu Lesmono yang berhubungan secara personal dengan ketua-ketua mitra ta'lim, bapak Jajat Eka O. Gunawan yang menindaklanjuti fixasi informasi kajian yang akan dipublikasikan dibatu oleh staf IT dan media yaitu Windi N. Fadilah dan M. Faris Al-Aziz serta Dadang Sopandi sebagi desainer grafis.

Pelaksanaan kegiatan kajian berjalan sesuai dengan waktu dan pengisi yang telah ditetapkan pada tahap perencanaan. Adapun pelaksanaan publikasi kegiatan yang dilakukan oleh bidang Humas masjid Agung Trans Studio Bandung ini meliputi: 1) penerimaan ajuan kegiatan dari mitra ta'lim melalui surat pengajuan resmi, 2) mendiskusikan pengisi, tema dan teknis pelasanaan kajian, 3) menerima poster kajian dan merevisinya jika perlu, dan 4) memastikan fixasi kajian 1 bulan sebelum hari pelaksanaan untuk kemudian di publikasikan di semua akun media sosial.

Pengawasan kegiatan publikasi kajian yang dilakukan DKM masjid Trans Studio Bandung dilakukan dengan suasana yang santai dan informal. Karena kegiatan dengan mitra ta'lim berjalan untuk jangka panjang dan media yang diganakan biasanya adalah aplikasi whatsapp apabila jarak jauh dan juga dengan lisan secara personal dengan penanggungjawab dari penyelenggara kegiatan. Ada pun secara keseluruhan proses pengawasan pengisi dan tema kajian secara langsung bidang Humas berkoordinasi dengan dewan Pembina yaitu Prof. Dr. KH Miftah Faridl.

Hasil penelitian ini diharapkan dapat menjadi sumbangan pemikiran tentang perkembangan ilmu komunikasi khususnya dalam konteks manajemen komunikasi organisasi diharapkan dapat menambah wawasan, rujukan, pengetahuan bahkan menjadi pedoman khususnya bagi para praktisi organisasi. Dengan demikian sangat disarankan kepada Prodi Komunikasi Penyiaran Islam unutk memperluas dan memperbanyak penelitian tentang manajemen komunikasi berbasis media agar pelaksanaan dakwah Islamiyah berbasis online dapat terpetakan secara ilmiah.

Penelitian ini diharapkan dapat menjadi sumbangan pemikiran terkait evaluasi sistem manajemen komunikasi komunikasi dalam internal masjid secara praktis. Agar dapat memberikan gambaran komunikasi yang selama ini dilakukan oleh masjid prespektif ilmu manajemen komunikasi. Maka dari itu, kepada DKM masjid Trans Studio untuk konsisten dan selalu update konten-konten pada setiap akun media sosialnya dan terus meningkatkan kualitas publikasi melalui perkembangan jaman.

Untuk para da'i yang berdakwah melalui lembaga, atau manajemen masjid untuk dapat menjadikan masjid yang dibinanya menjadi masjid yang berbasis media agar dapat lebih makmur dan memberikan bnyak manfaat kepada jamaahnya.

Penelitian ini diharapkan dapat menjadi gambaran umum bagi masyarakat 
S. Mariyam, Y. Z. Abidin, I. Rosyidi

umum tentang aktivitas Masjid Trans Studio Bandung. Maka utnuk jamaah secara umum, sangat dianjurkan untuk memnfaatkan media sebagai sumber informasi agamis yang dapat bermanfaat dan membeikan maslahat untuk umat.

\section{DAFTAR PUSTAKA}

Abidin, Y. Z. (2015). Manajemen Komunikasi: Filosofi, Konsep dan Aplikasi. Bandung: CV Pustaka Setia.

Aliyudin. (2010). Prinsip-prinsip Metode Dakwah Menurut Alquran. dalam Ilmu Dakwah: Academic Journal for Homiletic Studies, 4 (15), 1007-1022.

Ardianto, E. (2006). Komunikasi 2.0 Teorisasi dan Implikasi, Yogyakarta: ASPIKOM. Ayub, M. E., dkk. (1996). Manajemen Masjid, Jakarta: Gema Insani Pers.

Donosepoetro, M. (1982). Manajemen dalam Pengertian dan Pendidikan Berpikir, Surabaya: Usaha Nasional.

Dulwahab, E. (2010). Dakwah di Era Konvergensi Media. dalam Ilmu Dakwah: Academic Journal for Homiletic Studies, 5(16), 23.

Effendy, O. U. (2005). Ilmu Komunikasi Teori dan Praktek, Bandung: Rosda Karya.

Fisher, A. B. (1990). Teori-Teori Komunikasi, Bandung: Remadja Karya.

Japarudin. (2012). Media Massa Dan Dakwah. Jurnal Dakwah, 13 (1), 1411-5905. Juniawati. (2014). Dakwah Melalui Media Elektronik: Peran Dan Potensi Media Elektronik Dalam Dakwah Islam Di Kalimantan Barat. Jurnal Dakwah, 15 (2), 1411-5905.

Mulyana, Deddy. (2005). Ilmu Komunikasi Suatu Pengantar. Bandung, Remaja Rosdakarya.

Oetomo, J. (2006). Sejarah Sosial Media, Jakarta, Yayasan OBOR Indonesia.

Pidarta, M. (1989). Manajemen Pendidikan Islam, Cet. 1, Jakarta: Bina Aksara.

Rusman. (2009). Manajemen Kurikulum, Cet.1, Jakarta: Raja Grafindo Persada.

Siagian, S. P. (1997). Manajemen Strategik, Cet. 1, Jakarta: Gunung Agung.

Syafaruddin, (2005). Manajemen Lembaga Pendidikan Islam, Cet. 1, Jakarta: Ciputat Press.

Ummatin, K. (2008) Globalisasi Komunikasi Dan Tuntutan Dakwah Bermedia. Jurnal Dakwah, 9 (2), 1411-5905.

Tarwiah, S., \& Fatoni, U. (2016). Respon Netizen terhadap Dakwah bi al-Qalam KH Muhammad Arifin Ilham di Media Sosial. Tabligh: Jurnal Komunikasi dan Penyiaran Islam, 1(1), 87-104

Tohari, L. A., Fatoni, U., \& Muhlis, A. (2020). Strategi Dakwah Santri Dalam Menghadapi Berita Hoax di Media Sosial. Tabligh: Jurnal Komunikasi dan Penyiaran Islam, 5(2), 148-167

West, R., \& Turner, L. H. (2008). Teori Komunikasi: Analisis dan Aplikasi: Buku 2. Jakarta: Salemba Humaika.

Zamroni, M. (2009). Perkembangan Teknologi Komunikasi Dan Dampaknya Terhadap Kehidupan. Jurnal Dakwah, 10(2), 1411-5905. 